\title{
İşletmelerde Çevre Muhasebesi ve Diğer Çevresel Faaliyetlerin Gerçekleşme \\ Durumunun Araştırılması
}

Ayşen KORUKOĞLU ${ }^{1}$

\section{ÖZET}

Günümüzde iç ve dış ilgi gruplarının artan çevresel beklentileri, işletmelerin çevresel sorumluluk, duyarlılık ve faaliyetlerinde artışa yol açmıştır. Aynı zamanda işletmeler, daha iyi bir çevre anlayışına ve çevresel faaliyetleri hakkında topluma bilgi sağlama sorumluluğuna sahip olmaya başlamıştır. Bu çalışmada çevre muhasebesi ve diğer çevresel faaliyetlerin işletmelerde gerçekleşme durumu ele alınmış, İzmir ilinde farklı sektörlerde faaliyet gösteren işletmelere uygulanan anket çalışmasının sonuçları açıklayıcı veri analizi ve parametrik olmayan istatistiksel teknikler kullanılarak değerlendirilmiştir.

Anahtar Kelimeler : Çevre Muhasebesi, Yeşil Muhasebe, İşletmelerde Çevresel Faaliyetler, Açıklayıcı Veri Analizi

\section{A Study on the Realization of Environmental Accounting and Other Environmental Activities in Enterprises}

\begin{abstract}
Nowadays; the growing environmental expectations of internal and external stakeholders have led to an increase in the environmental responsibility, sensitivity and activities of the enterprises. At the same time, enterprises have started to have a better understanding of the environment and a responsibility to provide information to society about their environmental activities. This study focuses on the realization of environmental accounting and other
\end{abstract}


environmental activities in enterprises. A survey was carried out on enterprises in various sectors within Izmir province and the results were evaluated and reviewed using exploratory data analysis and nonparametric statistical techniques.

Keywords : Environmental Accounting, Green Accounting, Environmental Activities in Enterprises, Exploratory Data Analysis

\section{GÍRİş}

Günümüzde çevre sorunlarının hızla artması beraberinde tüm toplumlarda çevre bilincinin artmasına neden olmuş ve işletmelerden çevresel sorumluluk duygusu ile faaliyette bulunmaları yönünde beklentileri de artırmıştır. İşletmelerin işletme içi ve dışı ilgi gruplarının çevresel beklentilerini karşılayabilmesi için yeşil yönetim anlayışı ile amaçlarını ve politikalarını belirlemesi, örgüt yapısını ve yönetim bilgi sistemini oluşturması, üretim, pazarlama, muhasebe ve finansman, malzeme yönetimi, lojistik, halkla ilişkiler, araştırma ve geliştirme faaliyetlerini sürdürmeleri önem kazanmıştır.

Bir farklılaştırma stratejisi olarak yeşil hammadde, yeşil teknoloji, yeşil yatırım, yeşil ürün vb. hususların artan çevresel bilincin de etkisiyle yeşil pazarlar ve müşteriler açısından yeni rekabet alanları açmaya başlaması, çevresel maliyetlerin toplam maliyetler içindeki payının yükselmesi, sosyal ve çevresel sorumluluk bağlamında çevreye duyarlı yeşil işletme imajının öneminin kavranması işletmelerin veya yöneticilerin çevre muhasebesine olan ilgilerini artırmaktadır (Kırlığlu ve Can, 2006:70).

Literatürde yeşil muhasebe olarak da adlandırılan çevre muhasebesi, "bir şirketin çevre yönetimi, kalite yönetimi ve maliyet yönetiminden oluşan bütünün önemli bir parçasıdır” (EPA,1995,s.24). Çevre muhasebesi, “çevresel kaynakların oluşumunu, bu kaynakların kullanılış biçimini, işletmelerin faaliyetleri sonucunda bu kaynaklarda meydana gelen artış ve azalışları ve işletmelerin çevresel açıdan durumunu açıklayan bilgileri üreten ve bunları ilgili kişi ve kuruluşlara ileten bir bilgi sistemi” dir (Özbirecikli,2002:24). 
Çevre muhasebesi ile muhasebenin temel kavramlarından sosyal sorumluluk kavramının da etkisiyle;

- Çevresel sorumlulukların muhasebe sistemiyle bütünleştirilmesi,

- Çevre etken ve koşullarının saptanması, bunların olumsuz etkilerinin giderilmesine muhasebenin katkısının sağlanması,

- Çevresel sorunların giderilmesine yönelik maliyet analizlerinin yapılması,

- Çevresel kaynak envanterinin belli bir zamanda hangi düzeyde olduğunun saptanması hedeflenmektedir (Çelik,2007:154).

Çevre muhasebesinden beklenen yararın sağlanması ve ayrıca işletmelerin gelişmesi, rekabet avantajı elde etmesi ve çevresel beklentileri karşılayabilmesi açısından;

- Çevresel maliyetlerin doğru bir şekilde saptanması ve yönetilmesi,

- Çevresel performansın ölçülmesi ve iyileştirilebileceği alanların belirlenmesi,

- İşletmenin çevreyle olan ilişkisinin ve çevresel etkilerinin saptanması,

- Çeşitli işletme kararlarında ihtiyaç duyulan çevresel bilgilerin elde edilmesi,

- Çevre raporuyla işletmenin çevresel performansı ve çevresel etkilerine ilişkin

bilgilerin ilgi gruplarına düzenli olarak iletilmesi

faaliyetlerinin işletmelerde yürütülmesi gerekmektedir.

Bu çalışmada İzmir ilinde farklı sektörlerde faaliyet gösteren işletmelerde çevre muhasebesi ve diğer çevresel faaliyetlerin gerçekleşme durumu araştırılmıştır. Çalışmanın izleyen bölümünde literatür özetine daha sonraki bölümlerinde ise, açıklayıcı veri analizi ve parametrik olmayan istatistiksel teknikler kullanılarak değerlendirilen araştırma bulgularının sonuçları ve yorumlarına, konuyla ilgili önerilere yer verilmiştir. 


\section{LITERATÜR ÖZETI}

Literatürde çevre muhasebesi ve diğer çevresel faaliyetlere ilişkin çalışmaların bazıları ele alınıp özetlendiğinde; De Beer ve Friend (2006), çevre muhasebesinin işletmenin çevresel ve ekonomik performansını arttırmak için bir yönetim aracı olduğunu, Yakhou ve Dorweiler (2004) ise, işletme stratejisinin belirlenmesinde önem taşıdığını belirtmişlerdir. Güvemli ve Gökdeniz (1996), çevre muhasebesindeki gelişmeleri, Schaltegger vd. (2000), çağdaş çevresel muhasebe kavramlarını, uygulamalarını ve sorunlarını, Gönel ve Atabarut (2005) ise, işletmelerde çevre muhasebesinin uygulanışını farklı ülke uygulamalarından örnekler vererek ele almışlardır. EPA (US Environmental Protection Agency) (1995), işletme yönetim aracı olarak çevre muhasebesini açıklamış, Çelik (2007), çevreye duyarlı muhasebeyi farklı yönleriyle incelemiş, Kırlığlu ve Can (2006) ise, çevresel muhasebede kavramsal tartışmaların gelişimini ve analizini ele alarak gelecekte neler yapılması gerektiğini belirtmiş̧lerdir.

Savage vd. (2001), çevresel yönetim muhasebesi politikalarını, Maria (2006), seramik sektöründe çevresel yönetim muhasebesi uygulamalarını ve geliştirilen çevresel yönetim sistemlerini, Larojan ve Thevaruban (2014) ise, Sri Lanka'daki üretim işletmelerinde çevresel yönetim muhasebesi uygulamalarını ve bu uygulamaların işletmelerin finansal performansına etkilerini ele almışlardır. Özbirecikli (2002), çevresel nitelikteki maliyetlerin maliyet gruplarındaki payının ne olduğunu üç sektör bazında incelemiş, Alagöz ve İrdiren (2013), maliyet muhasebesi yönüyle işletmelerde çevre maliyetleri ve yönetimini, Alpaslan vd. (2012), Türkiye Finansal Raporlama Standartları kapsamında çevresel maliyetleri ve muhasebeleştirilmesini, Gale ve Stokoi (2001) ise, çevresel maliyet muhasebesi ve işletme stratejisi konularını ele almışlardır.

Li (2014), Çin petrol endüstrisinde faaliyet gösteren işletmelerin, Eltaib (2012) ise, Avustralya'daki petrol ve gaz şirketlerinin çevre muhasebesi uygulamalarını ve karşılaşılan 
sorunları araştırmışlar ve öneriler getirmişlerdir. Beredugo (2014), Nijerya'daki üretim işletmelerinde çevre muhasebesi ve sosyal sorumluluk faaliyetlerini ve bu faaliyetlerin işletme performanslarına olan etkilerini, Ali, Rashid ve Islam (2010) ise, Bangladeş’teki işletmelerde çevre muhasebesinin uygulanabilirliğini ve karşılaşılan sorunları ele almışlardır.

Korukoğlu (2014), işletmelerin çevre muhasebesi konularına yaklaşımlarını, Korukoğlu (2011), çevre muhasebesinin işletmelerde ne şekilde uygulandığını ve karşılaşılan sorunları, Lazol v.d (2008), çevre muhasebesinin KOBİ'lerde uygulanışını, Aslanertik ve Özgen (2007), otel işletmeleri açısından konunun önemini ve uygulanışını araştırmışlar, Deniz ve Türker (2012) ise, çevresel muhasebenin ormancılık sektöründeki yerini ve önemini ele almışlardır. Akatay ve Aslan (2008), işletmelerin yeşil yönetime duyarlılıklarını ve bu kapsamda işletmeleri ISO 14001 sertifikası almaya yönelten faktörleri, Cavlı (2009), işletmelerin çevresel sorumluluk çalışmalarını, Yüksel (2003) ise, işletmelerin çevreye duyarlı üretim faaliyetlerinin, çevre performansına ve işletme performansına olan etkilerini araştırmıştır. Kolar ve O’Connor (2004), Çek Cumhuriyeti'nde doğal kaynaklar ve çevre muhasebesinin ele alınışını, Zhang vd. (2009) ise, Çin'de kimya sektöründe faaliyet gösteren işletmelerde çevresel bilgilerin kullanımını ve bunun sonuçlarını, Reynolds ve Tilt (2013), yönetim muhasebesinin çevre stratejisi belirlemedeki katkısını Avustralya'daki işletmelerde araştırmışlardır.

\section{ARAŞTIRMANIN AMACI, KAPSAMI VE BULGULARI}

$\mathrm{Bu}$ çalışma, işletmelerde çevre muhasebesi uygulaması ve diğer çevresel alanlara yönelik hangi faaliyetlerin gerçekleştirildiğini ve gelecekte gerçekleştirilmek istendiğini araştırmak amacıyla yapılmıştır. İşletmelerin çevresel faaliyetlerinin bilinmesi, çevre muhasebesi uygulamasının başarılı bir şekilde yürütülmesi açısından önemli olmaktadır. Bu konuda Gönel ve Atabarut (2005), çevre muhasebesinin uygulanmasında, işletmenin temel faaliyetlerinin ve yapabileceklerinin, çevreyle olan ilişkisinin özellikle de çevreye olan 
etkilerinin çok iyi bilinmesi ve işletmenin “ekolojik ayak izi” nin (ecological footprint) çıkartılması gerektiğini belirtmiştir.

Araştırmanın kapsamını İzmir ilinde farklı sektörlerde faaliyet gösteren işletmeler oluşturmaktadır. Konuyla ilgili literatürden (Gönel ve Atabarut,2005; EPA,1995; Özbirecikli, 2002 vd.) yararlanılarak hazırlanan anket formu, on üç sektörde faaliyet gösteren 450 işletmeye internet ortamında gönderilmiş ve \% 20 geri dönüş sağlanmıştır. Özellikle yöneticilerin anket için zaman ayırmak istememeleri, bazı işletmelerde üst yönetimin anket için izin vermemesi, zamanında ve geçerli anket geri dönüşü olmaması geri dönüş oranını azaltan nedenler olmuştur. Çalışmada verileri geçerli bulunan on sektörden \% 12.9 geri dönüş oranı ile 58 işletmenin anket verisi değerlendirmeye alınmıştır. Söz konusu işletmelerin sektörel dağılımı; gıda (17), tekstil (2), inşaat (3), metal (5), otomotiv (3), elektronik (3), plastik (4), ambalaj (4), kimya (7) ve diğer (10) sektörler şeklinde olup, mobilya, maden ve deri sektörlerinden geri dönüş sağlanamamıştır. Çalışan sayısı açısından işletmelerin dağılımı; 1-9 arası çalışanı olan (2), 10-49 arası (7), 50-249 arası (20) ve 250 ve üzeri (28) işletme şeklindedir. İşletmelerin hukuki statüsü ise, anonim (48) ve limited (10) şirkettir.

Çalışmada çevre muhasebesi uygulaması ve diğer çevresel alanlara yönelik otuz beş farklı faaliyetin araştırma kapsamına giren işletmelerde gerçekleşme durumu araştırılmıştır. İşletmelerin söz konusu faaliyetlerin gerçekleşme durumuna "evet”, "hayır” ve “düşünülmekte” şeklinde verdikleri yanıtların iç tutarlılık ve güvenilirliklerini ölçmek amacıyla Cronbach's Alpha istatistiği hesaplanmış ve 0.93 sonucu elde edilmiştir. Bu sonuç, verilerin yeterli düzeyde tutarlı ve güvenilir olduğunu göstermektedir. Çalışmada iki yönlü tablolarda Khi-Kare katkı bileşenlerinin analizi, grafik sonuçlarla desteklenerek açıklayıcı veri analizi çerçevesinde incelenmiş ve yorumlanmıştır. Ayrıca çevresel faaliyetlerin gerçekleşme 
durumunun sektörler ve işletmelerin hukuki statüleri açısından farklılıkları, parametrik olmayan medyan testleri ile karşılaştırılmış ve sonuçları yorumlanmıştır.

Çevresel faaliyetlerin her biri için "evet", "hayır" ve "düşünülmekte” şeklinde verilen yanıtların frekansları ile incelenen işletmeler içerisindeki yüzdeleri ve ayrıca tüm "evet", "hayır" ve “düşünülmekte” yanıtları içerisindeki yüzdeleri Tablo-1' de verilmiştir. Söz konusu tablodaki değerler faaliyetler düzeyinde satır esaslı olarak incelendiğinde, genel olarak işletmeler içerisinde çevresel faaliyetlerin gerçekleşme durumuna verilen "evet" yanıtlarının ağırlıklı olduğu, "hayır" ve "düşünülmekte" yanıtlarında ise benzerliklerin ortaya çıktığı frekanslar ve yüzde değerlerinden anlaşılmaktadır. Tablo-1' den "evet", "hayır" ve "düşünülmekte" saptamalarında otuz beş faaliyet toplamında 1919 yanıt alındığ1 görülmektedir. Söz konusu saptamalarda 1101 evet yanıtı \%57.37 ile birinci sırada, 473 hayır yanıtı \% 24.65 ile ikinci ve 345 düşünülmekte yanıtı ise, \% 17.98 ile üçüncü sırada gelmiştir. Özellikle \% 60 ve üstü “evet” yanıtı verilerek gerçekleştiği belirtilen faaliyetler büyüklük siralamasinda;

- 21. İşletmede atık yönetimi birimi vardır,

- 20. İşletmede enerji yönetimi söz konusudur,

- 26. Çevresel emisyonun ölçümü ve zarar verici boyuta gelmesinin önlenmesi sağlanmıştır,

- 8. İşletmede mevcut ve ortaya çıkacak çevre sorunlarıyla ilgilenilmekte ve bunların çözümü için stratejiler belirlenmektedir,

- 23. Doğal kaynakların korunması için enerji ve malzeme kullanımı verimliliği çalışmaları yapılmaktadır,

- 24. Atıkların kullanılabilir ekonomik değerleri olan ürünlere dönüştürülmesi söz konusudur, 
Tablo-1: Çevresel Faaliyetlerin Gerçekleşme Durumuna İlişkin Yanıtların Frekans ve Yüzde Dağılımları

\begin{tabular}{|c|c|c|c|c|c|c|c|c|c|c|c|}
\hline \multirow{2}{*}{ Çevresel Faaliyetler } & \multicolumn{3}{|c|}{ Evet } & \multicolumn{3}{|c|}{ Hayır } & \multicolumn{3}{|c|}{ Düşünülmekte } & \multicolumn{2}{|c|}{ Toplam } \\
\hline & $\mathbf{n}$ & FY \% & SY \% & $\mathbf{n}$ & FY \% & SY \% & n & FY \% & SY \% & $\mathbf{n}$ & SY \% \\
\hline $\begin{array}{l}\text { 1. İşletmede gözden kaçırılmış çevresel gelirler veya } \\
\text { maliyet düşürücü imkânlar saptanmıştır }\end{array}$ & 26 & 50.00 & 2.36 & 17 & 32.69 & 3.594 & 9 & 17.31 & 2.609 & 52 & 2.710 \\
\hline $\begin{array}{l}\text { 2. Çevre muhasebesi uygulamasında mevcut muhasebe } \\
\text { sistemi gözden geçirilmiştir }\end{array}$ & 19 & 35.85 & 1.73 & 17 & 32.08 & 3.594 & 17 & 32.08 & 4.928 & 53 & 2.762 \\
\hline 3. Çevresel risk analizi yapılmaktadır & 40 & 72.73 & 3.63 & 8 & 14.55 & 1.691 & 7 & 12.73 & 2.029 & 55 & 2.866 \\
\hline 4. Çevre eğitim planları yapılmaktadır & 35 & 64.81 & 3.18 & 8 & 14.81 & 1.691 & 11 & 20.37 & 3.188 & 54 & 2.814 \\
\hline $\begin{array}{l}\text { 5. Yatırım politikalarının çevresel etkileri dikkate } \\
\text { alınmaktadır }\end{array}$ & 40 & 74.07 & 3.63 & 4 & 7.41 & 0.846 & 10 & 18.52 & 2.899 & 54 & 2.814 \\
\hline $\begin{array}{l}\text { 6. Çevresel performansın iyileştirilebileceği alanlar } \\
\text { belirlenmektedir }\end{array}$ & 37 & 68.52 & 3.36 & 5 & 9.26 & 1.057 & 12 & 22.22 & 3.478 & 54 & 2.814 \\
\hline $\begin{array}{l}\text { 7. Tasarım ve pazarlama aşamasında çevre ile ilgili } \\
\text { hususlar dikkate alınmaktadır }\end{array}$ & 32 & 58.18 & 2.91 & 11 & 20.00 & 2.326 & 12 & 21.82 & 3.478 & 54 & 2.866 \\
\hline $\begin{array}{l}\text { 8. İşletmede mevcut ve ortaya çıkacak çevre } \\
\text { sorunlarıyla ilgilenilmekte ve bunların çözümü } \\
\text { için stratejiler belirlenmektedir }\end{array}$ & 43 & 78.18 & 3.91 & 3 & 5.45 & 0.634 & 9 & 16.36 & 2.609 & 55 & 2.866 \\
\hline $\begin{array}{l}\text { 9. Potansiyel acil durumlar için çevresel tehlike ve risk } \\
\text { değerlendirmesi yapılmaktadır }\end{array}$ & 42 & 76.36 & 3.82 & 3 & 5.45 & 0.634 & 10 & 18.18 & 2.899 & 55 & 2.866 \\
\hline $\begin{array}{l}\text { 10.Çevresel performans ve halk sağlı̆̆ına yönelik } \\
\text { iyileştirmeler yapılmaktadır }\end{array}$ & 29 & 53.70 & 2.63 & 4 & 7.41 & 0.846 & 21 & 38.89 & 6.087 & 54 & 2.814 \\
\hline $\begin{array}{l}\text { 11.Çevresel etkinlikler ile ilgili olarak kamuoyuna } \\
\text { yönelik bir "çevre raporu" düzenlenmektedir }\end{array}$ & 10 & 18.87 & 0.91 & 34 & 64.15 & 7.188 & 9 & 16.98 & 2.609 & 53 & 2.762 \\
\hline
\end{tabular}

FY \% : Faaliyet İçindeki Yüzde $\quad$ SY \% : Sütun İçindeki Yüzde 
Tablo-1 (Devamı): Çevresel Faaliyetlerin Gerçekleşme Durumuna İlişkin Yanıtların Frekans ve Yüzde Dağılımları

\begin{tabular}{|c|c|c|c|c|c|c|c|c|c|c|c|}
\hline \multirow{2}{*}{ Çevresel Faaliyetler } & \multicolumn{3}{|c|}{ Evet } & \multicolumn{3}{|c|}{ Hayır } & \multicolumn{3}{|c|}{ Düşünülmekte } & \multicolumn{2}{|c|}{ Toplam } \\
\hline & $\mathbf{n}$ & FY \% & SY \% & $\mathbf{n}$ & FY \% & SY \% & $\mathbf{n}$ & FY \% & SY \% & $\mathbf{n}$ & SY \% \\
\hline $\begin{array}{l}\text { 12. Yatırımların çevre dostu faaliyetlere yönelmesi } \\
\text { sağlanmaktadır }\end{array}$ & 30 & 55.56 & 2.73 & 9 & 16.67 & 1.903 & 15 & 27.78 & 4.348 & 54 & 2.814 \\
\hline 13.İşletmenin önemli çevresel etkileri belirlenmiş̧tir & 39 & 70.91 & 3.54 & 11 & 20.00 & 2.326 & 5 & 9.09 & 1.449 & 54 & 2.866 \\
\hline $\begin{array}{l}\text { 14. İşletmenin komşularına yönelik çevre anketi (komşuların } \\
\text { şikayetlerinin belirlenmesi vb. konular için) } \\
\text { yapılmaktadır }\end{array}$ & 13 & 24.07 & 1.18 & 33 & 61.11 & 6.977 & 8 & 14.81 & 2.319 & 55 & 2.814 \\
\hline 15.Çevre ile ilgili sosyal faaliyetlere önem verilmektedir & 28 & 50.00 & 2.54 & 20 & 35.71 & 4.228 & 8 & 14.29 & 2.319 & 56 & 2.918 \\
\hline $\begin{array}{l}\text { 16.Çevre ile ilgili halkla ilişkiler ve iletişim (söyleşi, } \\
\text { seminer, ağaç dikme, orman vd) işletmede söz konusudur }\end{array}$ & 23 & 41.82 & 2.09 & 22 & 40.00 & 4.651 & 10 & 18.18 & 2.899 & 55 & 2.866 \\
\hline $\begin{array}{l}\text { 17. Her bir çevresel etkinin maliyetinin nereye kaydedileceği } \\
\text { belirlenmiştir }\end{array}$ & 28 & 51.85 & 2.54 & 13 & 24.07 & 2.748 & 13 & 24.07 & 3.768 & 54 & 2.814 \\
\hline 18.Çevresel maliyetler tanımlanmıştır & 32 & 57.14 & 2.91 & 8 & 14.29 & 1.69 & 16 & 28.57 & 4.64 & 56 & 2.918 \\
\hline $\begin{array}{l}\text { 19.Çevre muhasebesi uygulamasında kimlerin görev } \\
\text { alacağı belirlenmiştir }\end{array}$ & 21 & 36.84 & 1.91 & 21 & 36.84 & 4.44 & 15 & 26.32 & 4.35 & 57 & 2.970 \\
\hline 20.İşletmede enerji yönetimi söz konusudur & 49 & 84.48 & 4.45 & 4 & 6.90 & 0.85 & 5 & 8.62 & 1.45 & 58 & 3.022 \\
\hline 21. İsletmede atık yönetimi birimi vardır & 48 & 85.71 & 4.36 & 5 & 8.93 & 1.06 & 3 & 5.36 & 0.87 & 56 & 2.918 \\
\hline $\begin{array}{l}\text { 22.Üretim ve pazarlama politikaları ürünlerin çevresel } \\
\text { etkileri dikkate alınarak yeniden oluşturulmuştur }\end{array}$ & 27 & 47.37 & 2.45 & 20 & 35.09 & 4.23 & 10 & 17.54 & 2.90 & 57 & 2.970 \\
\hline $\begin{array}{l}\text { 23.Doğal kaynakların korunması için enerji ve malzeme } \\
\text { kullanımı verimliliği çalışmaları yapılmaktadır }\end{array}$ & 44 & 77.19 & 4.00 & 7 & 12.28 & 1.48 & 6 & 10.53 & 1.74 & 57 & 2.970 \\
\hline
\end{tabular}

FY \% : Faaliyet İçindeki Yüzde $\quad$ SY \% : Sütun İçindeki Yüzde 
Tablo-1 (Devamı): Çevresel Faaliyetlerin Gerçekleşme Durumuna İlişkin Yanıtların Frekans ve Yüzde Dağılımları

\begin{tabular}{|c|c|c|c|c|c|c|c|c|c|c|c|}
\hline \multirow{2}{*}{ Çevresel Faaliyetler } & \multicolumn{3}{|c|}{ Evet } & \multicolumn{3}{|c|}{ Hayır } & \multicolumn{3}{|c|}{ Düşünülmekte } & \multicolumn{2}{|c|}{ Toplam } \\
\hline & $\mathbf{n}$ & FY \% & SY \% & $\mathbf{n}$ & FY \% & SY \% & $\mathbf{n}$ & FY \% & SY \% & $\mathbf{n}$ & SY \% \\
\hline $\begin{array}{l}\text { 24.Atıkların kullanılabilir ekonomik değerleri olan } \\
\text { ürünlere dönüştürülmesi söz konusudur }\end{array}$ & 43 & 76.79 & 3.91 & 6 & 10.71 & 1.27 & 7 & 12.50 & 2.03 & 56 & 2.918 \\
\hline 25.Geri dönüşümlü malzeme kullanılmaktadır & 39 & 70.91 & 3.54 & 13 & 23.64 & 2.75 & 3 & 5.45 & 0.87 & 55 & 2.866 \\
\hline $\begin{array}{l}\text { 26.Çevresel emisyonun ölçümü ve zarar verici boyuta } \\
\text { gelmesinin önlenmesi sağlanmıştır }\end{array}$ & 45 & 80.36 & 4.09 & 5 & 8.93 & 1.06 & 6 & 10.71 & 1.74 & 56 & 2.918 \\
\hline $\begin{array}{l}\text { 27.Ar-Ge çalışmaları ile çevre dostu mamuller } \\
\text { geliştirilmektedir }\end{array}$ & 22 & 38.60 & 2.00 & 15 & 26.32 & 3.17 & 20 & 35.09 & 5.80 & 57 & 2.970 \\
\hline 28.Personele yönelik çevre eğitim programı düzenlenmiştir & 37 & 69.81 & 3.36 & 6 & 11.32 & 1.27 & 10 & 18.87 & 2.90 & 53 & 2.762 \\
\hline $\begin{array}{l}\text { 29.İşletmede çevresel etki değerlendirmesi (ÇED) } \\
\text { uygulanmaktadır }\end{array}$ & 29 & 53.70 & 2.63 & 22 & 40.74 & 4.65 & 3 & 5.56 & 0.87 & 54 & 2.814 \\
\hline 30.İ̧letme ÇEVKO Vakfı üyesidir & 26 & 47.27 & 2.36 & 23 & 41.82 & 4.86 & 6 & 10.91 & 1.74 & 55 & 2.866 \\
\hline 31.Yeşil nokta işaretli ambalajlar kullanılmaktadır & 30 & 55.56 & 2.73 & 20 & 37.04 & 4.23 & 4 & 7.41 & 1.16 & 54 & 2.814 \\
\hline 32.İşletmenin çevre sloganı vardır & 14 & 25.45 & 1.27 & 30 & 54.55 & 6.34 & 11 & 20.00 & 3.19 & 55 & 2.866 \\
\hline 33.Ürün reklamlarında çevre dostu imaj1 verilmektedir & 19 & 35.85 & 1.73 & 24 & 45.28 & 5.07 & 10 & 18.87 & 2.90 & 53 & 2.762 \\
\hline $\begin{array}{l}\text { 34.İşletmede çevre dostu mamul ve süreçler geliştirme } \\
\text { faaliyetleri yürütülmektedir }\end{array}$ & 29 & 54.72 & 2.63 & 11 & 20.75 & 2.33 & 13 & 24.53 & 3.77 & 53 & 2.762 \\
\hline $\begin{array}{l}\text { 35.İşletmede çevresel performansın denetlenmesi söz } \\
\text { konusudur }\end{array}$ & 33 & 60.00 & 3.00 & 11 & 20.00 & 2.33 & 11 & 20.00 & 3.19 & 55 & 2.866 \\
\hline TOPLAM & 1101 & 57.37 & 100 & 473 & 24.65 & 100 & 345 & 17.98 & 100 & 1919 & 100.0 \\
\hline
\end{tabular}

FY \% : Faaliyet İçindeki Yüzde $\quad$ SY \% : Sütun İçindeki Yüzde 
- 9. Potansiyel acil durumlar için çevresel tehlike ve risk değerlendirmesi yapılmaktadır,

- 5. Yatırım politikalarının çevresel etkileri dikkate alınmaktadır,

- 3. Çevresel risk analizi yapılmaktadır,

- 13. İşletmenin önemli çevresel etkileri belirlenmiştir,

- 25. Geri dönüşümlü malzeme kullanılmaktadır,

- 4. Çevre eğitim planları yapılmaktadır,

- 6. Çevresel performansın iyileştirilebileceği alanlar belirlenmektedir,

- 28. Personele yönelik çevre eğitim programı düzenlenmiştir

- 35. İşletmede çevresel performansın denetlenmesi söz konusudur

şeklinde sıralanmıştır.

Özbirecikli (2002)'nin üç sektör bazında (kimya, gıda ve otomotiv-beyaz eşya) yaptığı araştırmanın sonuçlarında da yukarıda belirtilen $21,26,23,24$ ve 28 no.lu faaliyetlerin işletmelerde gerçekleştiği görülmüştür. Korukoğlu (2014)'nun farklı sektörlerde gerçekleştirdiği araştırmanın sonuçlarında ise, işletmelerin çevre muhasebesi konularına katılımlarının genelde yüksek oranlarda çıktığı belirtilmiştir. Bu sonuçlar, işletmelerde oluşmaya başlayan çevre bilincini destekleme yönünde neler yapılması gerektiğini düşünmeyi de gerekli kılmaktadır.

Çevresel faaliyetlerin gerçekleşme durumuna ilişkin histogramlar ise Şekil-1'de verilmiştir. "Evet” şeklinde verilen yanıtlar ilk sırada yer almasına rağmen, Tablo-1 ve Şekil-1'de görüldügü gibi çevresel faaliyet bazında "evet”, "hayır” ve “düşünülmekte” şeklinde verilen yanıtlarda farklılıkların ortaya çıkması, işletmelerde faaliyetlerin gerçekleşme sonuçlarının farklı olabileceğini göstermektedir.

Yukarıda değinildiği gibi bazı faaliyetler için verilen "evet", "hayır” ve "düşünülmekte” yanıtlarının diğer faaliyet yanıtlarından farklı frekans ve oranlarda ortaya çıkmaları, konunun istatistiksel olarak araştırılması gerektiğini ortaya çıkarmış ve bu amaçla aşağıdaki 


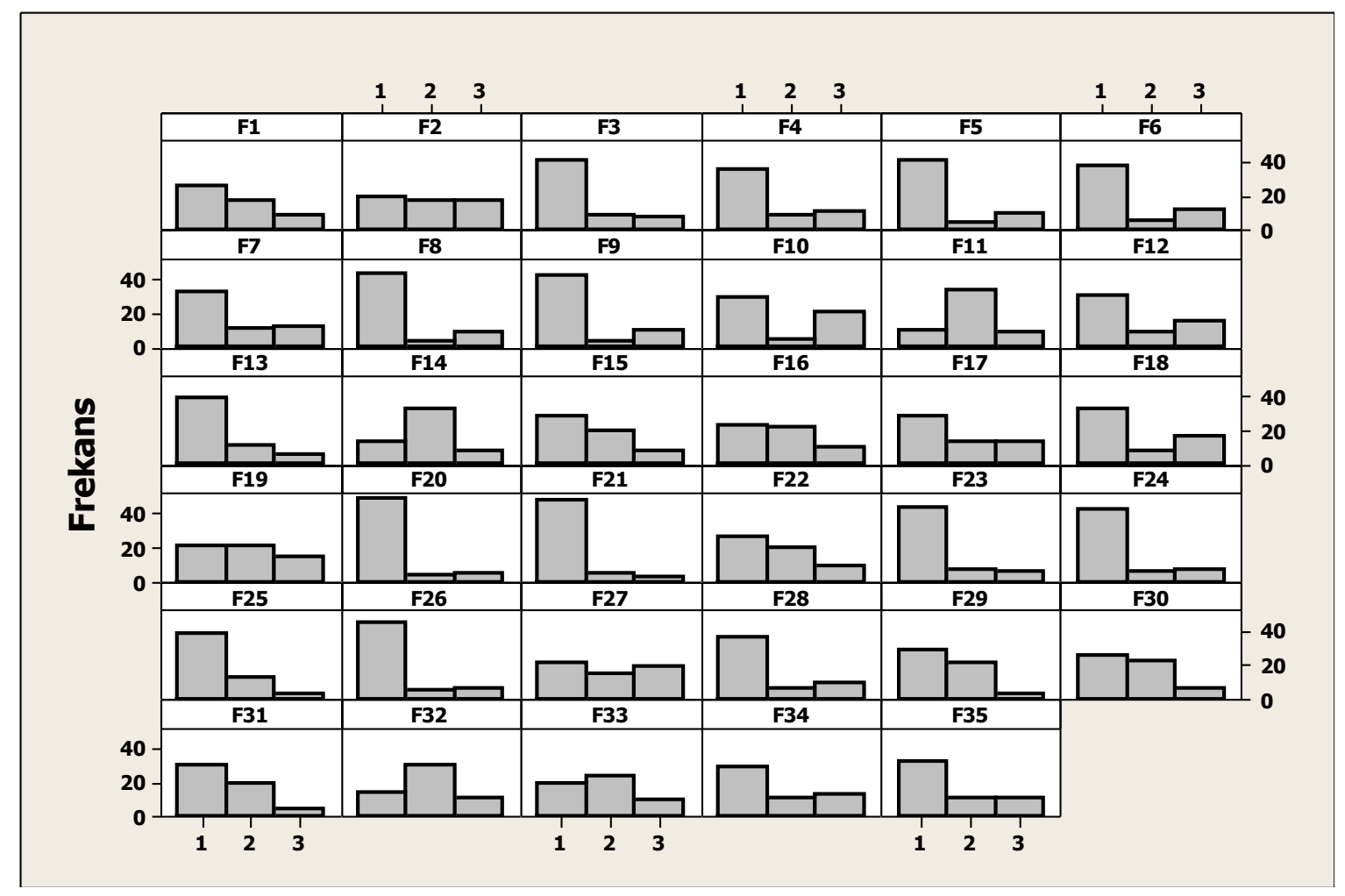

Şekil-1: Çevresel Faaliyetlerin Gerçekleşme Durumuna İlişkin Histogramlar

hipotezlerin kurulması söz konusu olmuştur. Bu doğrultuda;

$\mathrm{H}_{0}$ : İşletmelerde çevresel faaliyetlerin gerçekleşme durumuna "evet”, "hayır”,

“düşünülmekte” şeklinde verilen yanıtlar, ele alınan faaliyetlerden bağımsızdır,

$\mathrm{H}_{1}$ : İşletmelerde çevresel faaliyetlerin gerçekleşme durumuna “evet”, “hayır”,

“düşünülmekte” şeklinde verilen yanıtlar, ele alınan faaliyetler ile ilişkilidir

hipotezleri kurulmuştur. Yukarıdaki hipotezleri test etmek amacıyla Tablo-1'de verilen frekanslar kullanılarak iki yönlü tablolarda Khi-Kare bağımsızlık testi uygulanmış ve Pearson Khi-Kare İstatistiği (Pearson Chi-Square) $\chi^{2}=373.716$ olarak hesaplanmıştır. Elde edilen KhiKare istatistik değeri 0.001 düzeyinde anlamlı bulunmuştur (Serbestlik Derecesi:68, $\mathrm{p}<0.000$ ). $\mathrm{Bu}$ sonuca göre yukarıda verilen sıfır hipotezi reddedilmiş ve işletmelerden elde edilen "evet", "hayır" ve "düşünülmekte" yanıtlarının Tablo-1'de belirtilen faaliyetler ile ilişkili olduğu sonucuna varılmıştır. Ancak bu sonuç tüm faaliyetlerin yanıtlar bakımından birbirinden 
tamamen farklı oranlarda olduğu anlamına da gelmemektedir. $\mathrm{H}_{0}$ hipotezinin reddedilmesine yol açan faaliyet-yanıt etkileşiminin önemli olduğu konumlanmaları ortaya çıkarabilmek için yukarıda verilen Khi-Kare istatistik değerinin toplam $105(35 \times 3)$ tablo hücresinin her birindeki katkı bileşenini incelemek gerekmektedir. Bu amaçla Tablo-1 de verilen tüm tablo hücreleri için elde edilmiş frekanslara ek olarak $\mathrm{H}_{0}$ bağımsızlık hipotezi kapsamında beklenen frekans değerleri ve bunlarla birlikte hesaplanan hücresel Khi-Kare katkı bileşenleri Tablo-2 de verilmiştir.

Tablo-2 incelendiğinde, bazı hücresel konumlarda gerçekleştirilen hipotez testinin sonucuna bağlı olarak aykırılık ve etkileşimler görülmektedir. Ancak Tablo-2 çok sayıda hücre bilgisi içerdiğinden, değiş̧imleri ortaya koyabilmenin zorluğu da ortaya çıkmaktadır. Çevresel faaliyet-yanıt etkileşiminin ön plana çıktığı durumları belirlemede Tablo-2'de verilen KhiKare katkı bileşenlerinin yatay ve dikey değişimini göstermek önem kazanmaktadır. Çalışma kapsamında Khi-Kare katkı bileşenleri açıklayıcı veri analizi uygulaması olarak "evet", "hayır" ve "düşünülmekte" yanıtları ile faaliyet temelinde "toplam” değerler için yüzdesel olarak hesaplanmış ve büyükten küçüğe azalan sırada sütun diyagramları hazırlanmıştır.

Khi-Kare katkı değerlerinin sıralanmış katkı yüzdeleri dağılımı; Şekil-2'de “evet”, Şekil-3'de “hayır”, Şekil-4'de “düşünülmekte” yanıtları için ve Şekil-5'de “toplam” olarak verilmiştir. Söz konusu şekillerde yatay eksenler büyüklük sıra değerlerine, düşey eksenler ise faaliyet bazında Khi-Kare yüzde katkı değerlerine karşılık gelmekte olup, faaliyet sıra numaraları da yorum kolaylığı sağlama açısından ayrıca sütun diyagramlarına yerleştirilmiştir. Şekillerde yer alan diyagramlar incelendiğinde, çevresel faaliyet-yanıt etkileşimine yol açan ve dolayısıyla $\mathrm{H}_{0}$ bağımsızlık hipotezinin reddedilmesinde ön planda olan faaliyetler açıkça görülmektedir. 
Tablo-2: Çevresel Faaliyetlerin Gerçekleşme Durumu İle Beklenen Frekansları ve Khi-Kare Katkı Bileşenlerinin Dağılımı

\begin{tabular}{|c|c|c|c|c|c|c|c|c|c|c|c|}
\hline \multirow{2}{*}{ Çevresel Faaliyetler } & \multicolumn{3}{|c|}{ Evet } & \multicolumn{3}{|c|}{ Hayır } & \multicolumn{3}{|c|}{ Düşünülmekte } & \multicolumn{2}{|c|}{ Toplam } \\
\hline & $\mathbf{n}$ & BF & $\mathbf{K}$ & $\mathbf{n}$ & BF & $\mathbf{K}$ & $\mathbf{n}$ & BF & $\mathbf{K}$ & $\mathbf{n}$ & $\mathbf{K}$ \\
\hline $\begin{array}{l}\text { 1. İşletmede gözden kaçırılmış çevresel gelirler veya } \\
\text { maliyet düşürücü imkânlar saptanmıştır }\end{array}$ & 26 & 29.83 & 0.493 & 17 & 12.82 & 1.365 & 9 & 9.35 & 0.013 & 52 & 1.871 \\
\hline $\begin{array}{l}\text { 2. Çevre muhasebesi uygulamasında mevcut muhasebe } \\
\text { sistemi gözden geçirilmiştir. }\end{array}$ & 19 & 30.41 & 4.280 & 17 & 13.06 & 1.186 & 17 & 9.53 & 5.859 & 53 & 11.325 \\
\hline 3. Çevresel risk analizi yapılmaktadır & 40 & 31.56 & 2.260 & 8 & 13.56 & 2.278 & 7 & 9.89 & 0.844 & 55 & 5.381 \\
\hline 4. Çevre eğitim planları yapılmaktadır & 35 & 30.98 & 0.521 & 8 & 13.31 & 2.119 & 11 & 9.71 & 0.172 & 54 & 2.812 \\
\hline 5. Yatırım politikalarının çevresel etkileri dikkate alınmaktadır & 40 & 30.98 & 2.625 & 4 & 13.31 & 6.512 & 10 & 9.71 & 0.009 & 54 & 9.146 \\
\hline $\begin{array}{l}\text { 6. Çevresel performansın iyileştirilebileceği alanlar } \\
\text { belirlenmektedir }\end{array}$ & 37 & 30.98 & 1.169 & 5 & 13.31 & 5.188 & 12 & 9.71 & 0.541 & 54 & 6.898 \\
\hline $\begin{array}{l}\text { 7. Tasarım ve pazarlama aşamasında çevre ile ilgili hususlar } \\
\text { dikkate alınmaktadır }\end{array}$ & 32 & 31.56 & 0.006 & 11 & 13.56 & 0.482 & 12 & 9.89 & 0.451 & 54 & 0.940 \\
\hline $\begin{array}{l}\text { 8. İşletmede mevcut ve ortaya çıkacak çevre sorunlarıyla } \\
\text { ilgilenilmekte ve bunların çözümü için stratejiler } \\
\text { belirlenmektedir }\end{array}$ & 43 & 31.56 & 4.151 & 3 & 13.56 & 8.220 & 9 & 9.89 & 0.080 & 55 & 12.451 \\
\hline $\begin{array}{l}\text { 9. Potansiyel acil durumlar için çevresel tehlike ve risk } \\
\text { değerlendirmesi yapılmaktadır }\end{array}$ & 42 & 31.56 & 3.457 & 3 & 13.56 & 8.220 & 10 & 9.89 & 0.001 & 55 & 11.679 \\
\hline $\begin{array}{l}\text { 10.Çevresel performans ve halk sağlığına yönelik } \\
\text { iyileştirmeler yapılmaktadır }\end{array}$ & 29 & 30.98 & 0.127 & 4 & 13.31 & 6.512 & 21 & 9.71 & 13.134 & 54 & 19.773 \\
\hline $\begin{array}{l}\text { 11.Çevresel etkinlikler ile ilgili olarak kamuoyuna yönelik } \\
\text { bir "çevre raporu" düzenlenmektedir }\end{array}$ & 10 & 30.41 & 13.697 & 34 & 13.06 & 33.55 & 9 & 9.53 & 0.029 & 53 & 47.280 \\
\hline
\end{tabular}

BF: Beklenen Frekanslar K: Hücresel Khi-Kare Katkı Bileşeni 
Tablo-2 (Devamı): Çevresel Faaliyetlerin Gerçekleşme Durumu İle Beklenen Frekansları ve Khi-Kare Katkı Bileşenlerinin Dağılımı

\begin{tabular}{|c|c|c|c|c|c|c|c|c|c|c|c|}
\hline \multirow{2}{*}{ Çevresel Faaliyetler } & \multicolumn{3}{|c|}{ Evet } & \multicolumn{3}{|c|}{ Hayır } & \multicolumn{3}{|c|}{ Düşünülmekte } & \multicolumn{2}{|c|}{ Toplam } \\
\hline & $\mathbf{n}$ & BF & $\mathbf{K}$ & $\mathbf{n}$ & BF & $\mathbf{K}$ & $\mathbf{n}$ & BF & $\mathbf{K}$ & $\mathbf{n}$ & $\mathbf{K}$ \\
\hline $\begin{array}{l}\text { 12. Yatırımların çevre dostu faaliyetlere yönelmesi } \\
\text { sağlanmaktadır }\end{array}$ & 30 & 30.98 & 0.031 & 9 & 13.31 & 1.396 & 15 & 9.71 & 2.885 & 54 & 4.311 \\
\hline 13.İşletmenin önemli çevresel etkileri belirlenmiştir & 39 & 31.56 & 1.756 & 11 & 13.56 & 0.482 & 5 & 9.89 & 2.416 & 54 & 4.655 \\
\hline $\begin{array}{l}\text { 14.İşletmenin komşularına yönelik çevre anketi (komşuların } \\
\text { şikayetlerinin belirlenmesi vb. konular için) yapılmaktadır }\end{array}$ & 13 & 30.98 & 10.437 & 33 & 13.31 & 29.13 & 8 & 9.71 & 0.301 & 55 & 39.865 \\
\hline 15.Çevre ile ilgili sosyal faaliyetlere önem verilmektedir & 28 & 32.13 & 0.531 & 20 & 13.80 & 2.782 & 8 & 10.07 & 0.425 & 56 & 3.738 \\
\hline $\begin{array}{l}\text { 16.Çevre ile ilgili halkla ilişkiler ve iletişim (söyleşi, } \\
\text { seminer, ağaç dikme, orman vd) işletmede söz konusudur }\end{array}$ & 23 & 31.56 & 2.320 & 22 & 13.56 & 5.259 & 10 & 9.89 & 0.001 & 55 & 7.580 \\
\hline $\begin{array}{l}\text { 17. Her bir çevresel etkinin maliyetinin nereye kaydedileceği } \\
\text { belirlenmiştir }\end{array}$ & 28 & 30.98 & 0.287 & 13 & 13.31 & 0.007 & 13 & 9.71 & 1.116 & 54 & 1.410 \\
\hline 18.Çevresel maliyetler tanımlanmıştır & 32 & 32.13 & 0.001 & 8 & 13.80 & 2.440 & 16 & 10.07 & 3.496 & 56 & 5.936 \\
\hline $\begin{array}{l}\text { 19.Çevre muhasebesi uygulamasında kimlerin görev alacağı } \\
\text { belirlenmiştir }\end{array}$ & 21 & 32.70 & 4.188 & 21 & 14.05 & 3.439 & 15 & 10.25 & 2.204 & 57 & 9.831 \\
\hline 20.İşletmede enerji yönetimi söz konusudur & 49 & 33.28 & 7.429 & 4 & 14.30 & 7.415 & 5 & 10.43 & 2.825 & 58 & 17.669 \\
\hline 21.İşletmede atık yönetimi birimi vardır & 48 & 32.13 & 7.840 & 5 & 13.80 & 5.614 & 3 & 10.07 & 4.962 & 56 & 18.4155 \\
\hline $\begin{array}{l}\text { 22.Üretim ve pazarlama politikaları ürünlerin çevresel etkileri } \\
\text { dikkate alınarak yeniden oluşturulmuştur }\end{array}$ & 27 & 32.70 & 0.995 & 20 & 14.05 & 2.520 & 10 & 10.25 & 0.006 & 57 & 3.521 \\
\hline $\begin{array}{l}\text { 23.Doğal kaynakların korunması için enerji ve malzeme } \\
\text { kullanımı verimliliği çalışmaları yapılmaktadır }\end{array}$ & 44 & 32.70 & 3.903 & 7 & 14.05 & 3.537 & 6 & 10.25 & 1.761 & 57 & 9.200 \\
\hline
\end{tabular}

BF: Beklenen Frekanslar $\quad$ K: Hücresel Khi-Kare Katk1 Bileșeni 
Tablo-2 (Devamı): Çevresel Faaliyetlerin Gerçekleşme Durumu İle Beklenen Frekansları ve Khi-Kare Katkı Bileşenlerinin Dağılımı

\begin{tabular}{|c|c|c|c|c|c|c|c|c|c|c|c|}
\hline \multirow{2}{*}{ Çevresel Faaliyetler } & \multicolumn{3}{|c|}{ Evet } & \multicolumn{3}{|c|}{ Hayır } & \multicolumn{3}{|c|}{ Düşünülmekte } & \multicolumn{2}{|c|}{ Toplam } \\
\hline & $\mathbf{n}$ & BF & $\mathbf{K}$ & $\mathbf{n}$ & BF & $\mathbf{K}$ & $\mathbf{n}$ & BF & $\mathbf{K}$ & $\mathbf{n}$ & $\mathbf{K}$ \\
\hline $\begin{array}{l}\text { 24.Atıkların kullanılabilir ekonomik değerleri olan ürünlere } \\
\text { dönüştürülmesi söz konusudur }\end{array}$ & 43 & 32.13 & 3.678 & 6 & 13.80 & 4.411 & 7 & 10.07 & 0.935 & 56 & 9.024 \\
\hline 25.Geri dönüşümlü malzeme kullanılmaktadır & 39 & 31.56 & 1.756 & 13 & 13.56 & 0.023 & 3 & 9.89 & 4.798 & 55 & 6.577 \\
\hline $\begin{array}{l}\text { 26.Çevresel emisyonun ölçümü ve zarar verici boyuta } \\
\text { gelmesinin önlenmesi sağlanmıştır }\end{array}$ & 45 & 32.13 & 5.159 & 5 & 13.80 & 5.614 & 6 & 10.07 & 1.644 & 56 & 12.414 \\
\hline $\begin{array}{l}\text { 27.Ar-Ge çalışmaları ile çevre dostu mamuller } \\
\text { geliştirilmektedir }\end{array}$ & 22 & 32.70 & 3.503 & 15 & 14.05 & 0.064 & 20 & 10.25 & 9.281 & 57 & 12.848 \\
\hline 28.Personele yönelik çevre eğitim programı düzenlenmiştir & 37 & 30.41 & 1.429 & 6 & 13.06 & 3.819 & 10 & 9.53 & 0.023 & 53 & 5.272 \\
\hline $\begin{array}{l}\text { 29. İşletmede çevresel etki değerlendirmesi (ÇED) } \\
\text { uygulanmaktadır }\end{array}$ & 29 & 30.98 & 0.127 & 22 & 13.31 & 5.674 & 3 & 9.71 & 4.635 & 54 & 10.436 \\
\hline 30.İşletme ÇEVKO Vakfı üyesidir & 26 & 31.56 & 0.978 & 23 & 13.56 & 6.578 & 6 & 9.89 & 1.529 & 55 & 9.085 \\
\hline 31.Yeşil nokta işaretli ambalajlar kullanılmaktadır & 30 & 30.98 & 0.031 & 20 & 13.31 & 3.363 & 4 & 9.71 & 3.356 & 54 & 6.750 \\
\hline 32.İşletmenin çevre sloganı vardır & 14 & 31.56 & 9.767 & 30 & 13.56 & 19.945 & 11 & 9.89 & 0.125 & 55 & 29.837 \\
\hline 33.Ürün reklamlarında çevre dostu imajı verilmektedir & 19 & 30.41 & 4.280 & 24 & 13.06 & 9.156 & 10 & 9.53 & 0.023 & 53 & 13.459 \\
\hline $\begin{array}{l}\text { 34.İşletmede çevre dostu mamul ve süreçler geliştirme } \\
\text { faaliyetleri yürütülmektedir }\end{array}$ & 29 & 30.41 & 0.065 & 11 & 13.06 & 0.326 & 13 & 9.53 & 1.265 & 53 & 1.656 \\
\hline $\begin{array}{l}\text { 35.İşletmede çevresel performansin denetlenmesi söz } \\
\text { konusudur }\end{array}$ & 33 & 31.56 & 0.066 & 11 & 13.56 & 0.482 & 11 & 9.89 & 0.125 & 55 & 0.673 \\
\hline TOPLAM & 1101 & 1101 & 103.34 & 473 & 473 & 199.11 & 345 & 345 & 71.27 & 1919 & 373.716 \\
\hline
\end{tabular}

BF: Beklenen Frekanslar $\quad$ K: Hücresel Khi-Kare Katkı Bileşeni 


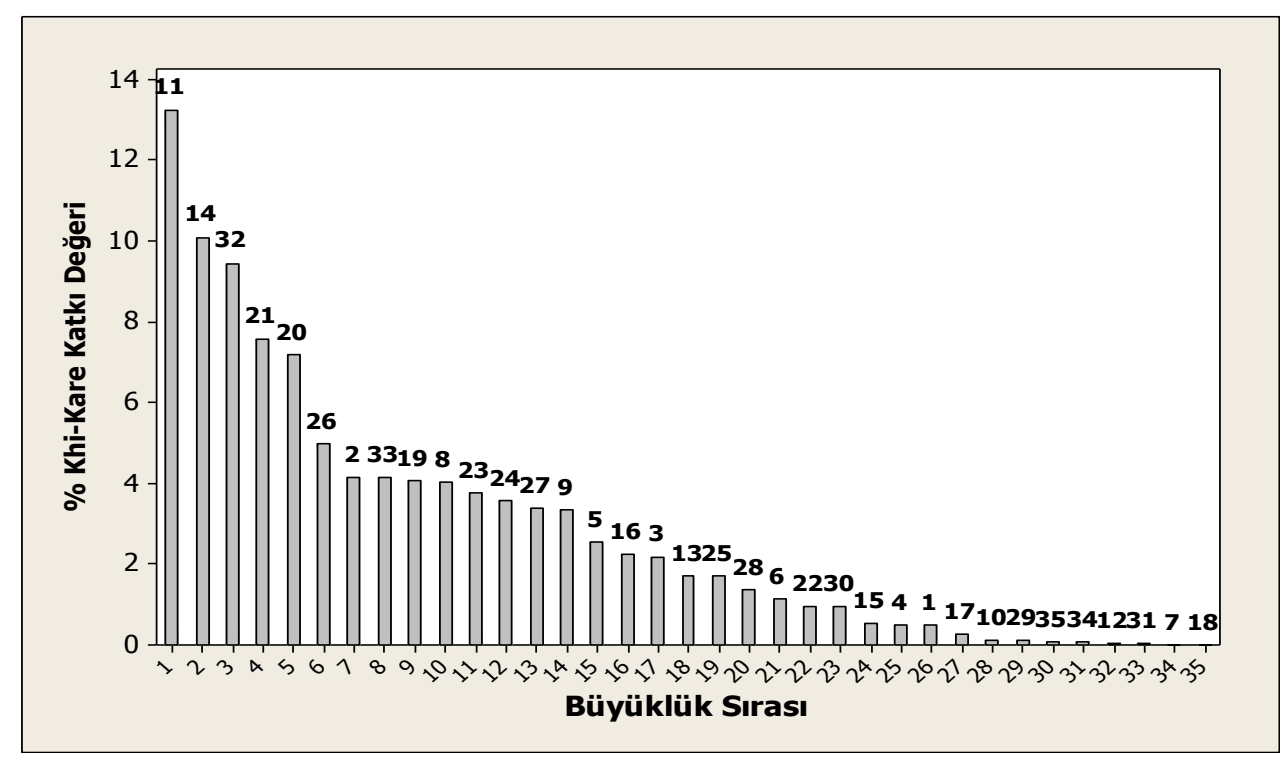

Şekil-2: "Evet” Yanıtları İçin Khi-Kare Katkı Değerlerinin Sıralanmış Katkı Yüzdeleri Dăğlımı

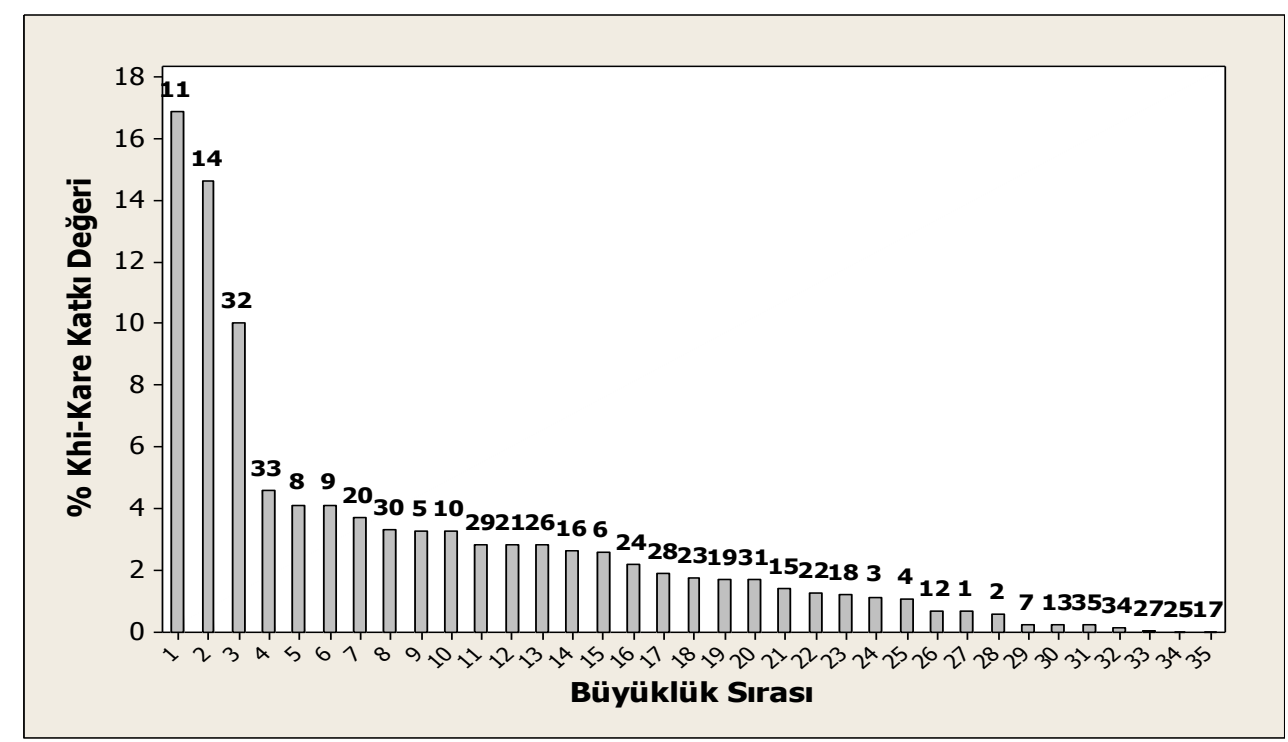

Şekil-3: "Hayır" Yanıtları İçin Khi-Kare Katkı Değerlerinin Sıralanmış Katk1 Yüzdeleri Dağılımı 
Şekil-2 ve Şekil-3'de, "evet" ve "hayır" yanıtlarına karşılık gelen diyagramlardan çevresel faaliyet-yanıt etkileşimini ortaya koyan ilk üç faaliyet,

- 11. Çevresel etkinlikler ile ilgili olarak kamuoyuna yönelik bir "çevre raporu" düzenlenmektedir,

- 14. İşletmenin komşularına yönelik çevre anketi (komşuların şikayetlerinin belirlenmesi vb. konular için) yapılmaktadır,

- 32. İşletmenin çevre sloganı vardır

şeklinde sıralanmıştır. $\mathrm{Bu}$ faaliyetler için Tablo-2'de bağımsızlık varsayımı altında belirlenmiş beklenen evet yanıt sayısının çok altında evet yanıtı alınırken, beklenen hayır yanıt sayısının çok üstünde hayır yanıtı alınmıştır. Yukarıda belirtilen 11, 14 ve 32 numaralı çevresel faaliyetler için bağımsızlık varsayımında beklenen evet yanıt frekansları Tablo-2’ de sırasıyla $30.41,30.98$ ve 31.56 olarak yer alırken, karşılık gelen gerçekleşmiş evet yanıt sayıları 10, 13 ve 14 değerlerinde kalmıştır. Buna karşılık söz konusu faaliyetler için beklenen hayır yanıt frekansları Tablo-2' de sırasıyla 13.06, 13.31 ve 13.56 iken, karşılık gelen gerçekleşmiş hayır yanıt sayılarının ise, bunların çok üzerinde 34, 33 ve 30 olduğu belirlenmiştir. $\mathrm{Bu}$ durumu, Tablo-1'de verilen çevresel faaliyetlerin gerçekleşme oranları incelendiğinde "Çevresel etkinlikler ile ilgili olarak kamuoyuna yönelik bir çevre raporu düzenlenmektedir" faaliyetinin \% 64.15, “İşletmenin komşularına yönelik çevre anketi (komşuların şikayetlerinin belirlenmesi vb. konular için) yapılmaktadır” faaliyetinin \% 61.11 ve "İşletmenin çevre sloganı vardır" faaliyetinin ise \% 54.55 ile işletmeler tarafından en yüksek oranlarda hayır yanıtı ile gerçekleşmeyen ilk üç faaliyet olması desteklemektedir. Belirtilen faaliyetlere ait Khi-Kare katkı yüzdelerinin evet yanıtlarındaki toplamı $\% 32.81$ düzeyinde iken, aynı uygulamaların toplam katkı bileşeni \% 41.50 düzeyine çıkmıştır. 
Yukarıda bahsedilen faaliyetlerin gerçekleşme durumuna yönelik verilen "düşünülmekte" yanıtı açısından toplam katkı bileşeni ise sadece \% 0.65 düzeyinde kalmıştır. Bu sonuçlar ilgili faaliyetler temelinde çevresel faaliyet-yanıt etkileşiminin önemini vurgulamaktadır.

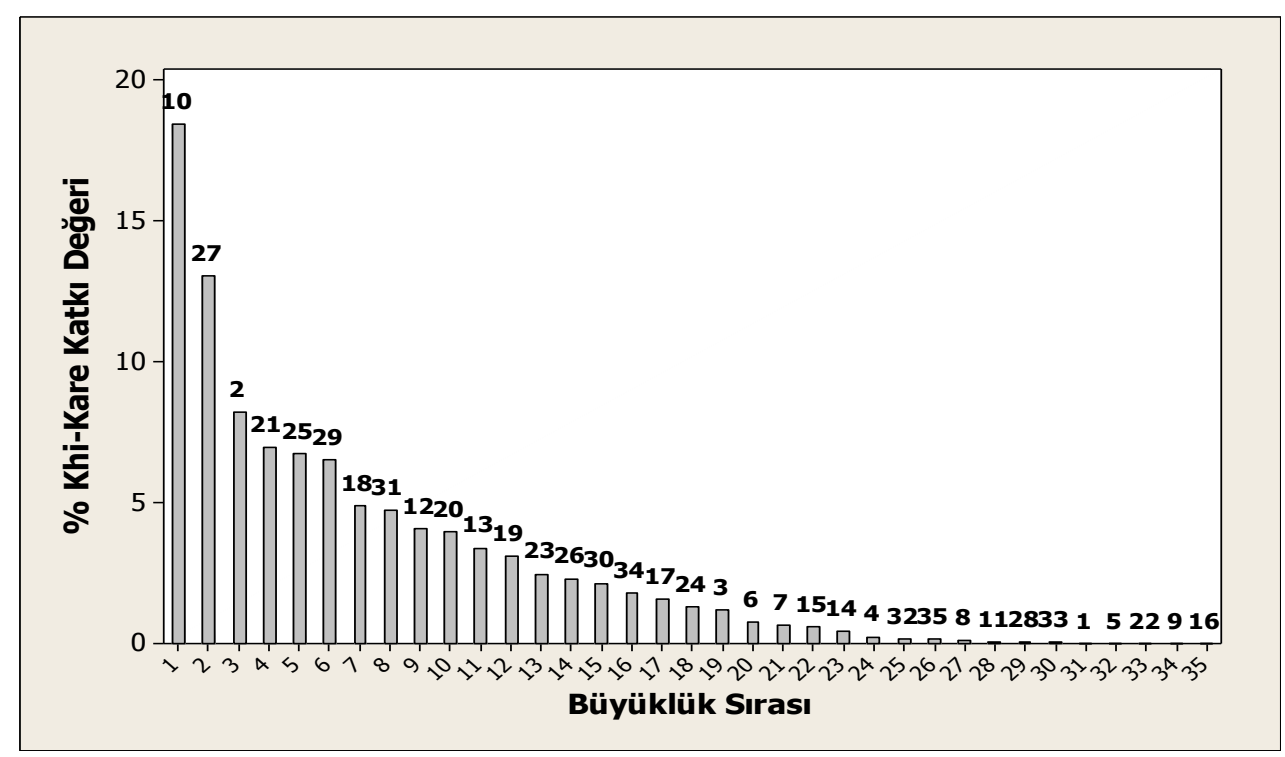

Şekil-4: “Düşünülmekte” Yanıtları İçin Khi-Kare Katkı Değerlerinin Sıralanmış Katkı Yüzdeleri Dağılımı

Şekil-4'de görülen “düşünülmekte” yanıtı için faaliyet-yanıt etkileşiminde öne çıkan ilk üç faaliyet ise;

- 10. Çevresel performans ve halk sağlığına yönelik iyileştirmeler yapılmaktadır,

- 27. Ar-Ge çalışmaları ile çevre dostu mamuller geliştirilmektedir,

- 2. Çevre muhasebesi uygulamasında mevcut muhasebe sistemi gözden geçirilmiştir şeklinde sıralanmıştır. $\mathrm{Bu}$ faaliyetler için Tablo-2'de bağımsızlık varsayımı altında belirlenmiş beklenen düşünülmekte yanıt sayısının çok üzerinde düşünülmekte yanıtları verildiği görülmektedir. Söz konusu faaliyetler için beklenen düşünülmekte yanıt frekansları Tablo-2’ de sırasıyla 9.71, 10.25 ve 9.53 iken, karş1lık gelen gerçekleşmiş düşünülmekte yanıt sayılarının ise bunların çok üzerinde 21, 20 ve 17 olduğu belirlenmiştir. Belirtilen faaliyetlere ait Khi-Kare katkı yüzdelerinin toplamı \% 39.67 olarak hesaplanmıştır. 


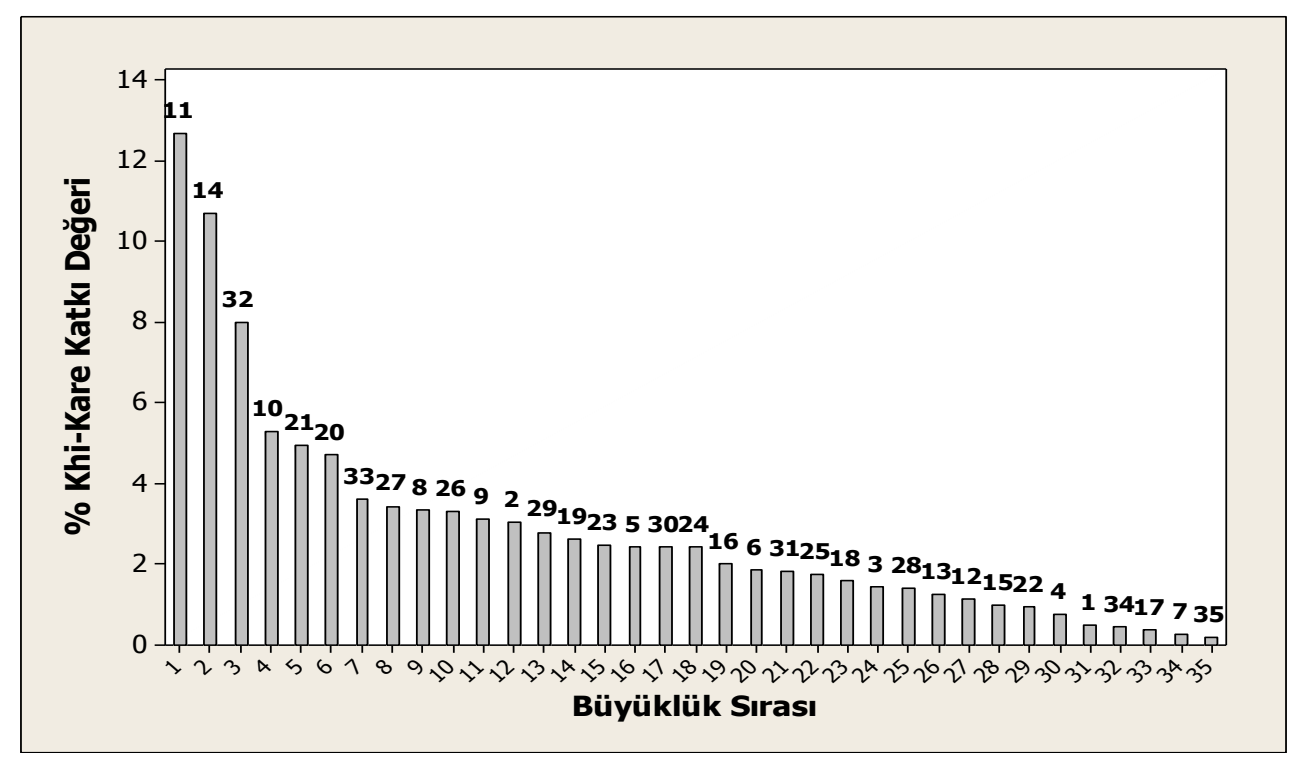

Şekil-5: Faaliyet Toplamında Khi-Kare Katkı Değerlerinin Sıralanmış Katkı Yüzdeleri Dağılımı

Çevresel faaliyetler için toplam olarak Khi-Kare katkı yüzdelerinin verildiği Şekil-5 incelendiğinde faaliyet-yanıt etkileşimini destekleyen ilk altı faaliyetin sırasıyla;

- 11. Çevresel etkinlikler ile ilgili olarak kamuoyuna yönelik bir "çevre raporu" düzenlenmektedir,

- 14. İşletmenin komşularına yönelik çevre anketi (komşuların şikayetlerinin belirlenmesi vb. konular için) yapılmaktadır,

- 32. İşletmenin çevre sloganı vardır,

- 10. Çevresel performans ve halk sağlığına yönelik iyileştirmeler yapılmaktadır,

- 21. İşletmede atık yönetimi birimi vardır,

- 20. İşletmede enerji yönetimi söz konusudur

olduğu görülmektedir.

Söz konusu altı faaliyetin Khi-Kare katkı bileşenlerinin toplamı, toplam Khi-Kare istatistiği içerisinde \% 46.25 olarak hesaplanmıştır. Yukarıda belirtilen ilk üç faaliyet, Şekil-2 ve Şekil3' de evet ve hayır yanıtı yönüyle, dördüncü sıradaki faaliyet ise Şekil-4' de düşünülmekte yanıtı yönüyle çevresel faaliyet-yanıt etkileşiminde ilk sırada yer almaktadır. Beşinci ve altıncı sırada yer alan faaliyetler ise evet yönüyle faaliyet-yanıt etkileşiminde dördüncü ve 
beşinci sırada ortaya çıkmaktadırlar. Çalışmada ayrıca ele alınan çevresel faaliyetlerin işletmelerde gerçekleşme durumunun sektörler bazında farklılıkları araştırılmıştır. Bu amaçla Mood Medyan testi ile her bir çevresel faaliyetin gerçekleşme durumu için sektör medyanları karşılaştırılmış ve sonuçlar Tablo-3' de verilmiştir. Söz konusu tablo değerleri incelendiğinde;

- 4. Çevre eğitim planları yapılmaktadır,

- 14. İşletmenin komşularına yönelik çevre anketi (komşuların şikayetlerinin belirlenmesi vb. konular için) yapılmaktadır,

- 28. Personele yönelik çevre eğitim programı düzenlenmiştir faaliyetlerine verilen yanıtların sektör medyanlarının karşılaştırılmasına ilişkin istatistikler için olasılık düzeyleri, $\mathrm{p}<0.01$ olarak elde edilmiştir. $\mathrm{Bu}$ sonuca göre belirtilen çevresel faaliyetlerin gerçekleşme durumları için sektörler arasında \% 99 düzeyinde istatistiksel olarak anlamlı farklılık bulunmuştur. Ayrıca;

- 1. İşletmede gözden kaçırılmış çevresel gelirler veya maliyet düşürücü imkânlar saptanmıştır,

- 11. Çevresel etkinlikler ile ilgili olarak kamuoyuna yönelik bir "çevre raporu" düzenlenmektedir,

- 19. Çevre muhasebesi uygulamasında kimlerin görev alacağı belirlenmiştir,

- 27. Ar-Ge çalışmaları ile çevre dostu mamuller geliştirilmektedir,

- 28. Personele yönelik çevre eğitim programı düzenlenmiştir,

- 30. İşletme ÇEVKO Vakfi üyesidir,

- 32. İşletmenin çevre sloganı vardır faaliyetlerine verilen yanıtların sektör medyanlarının karşılaştırılmasına ilişkin istatistikler için olasılık düzeyleri ise, $\mathrm{p}<0.05$ olarak elde edilmiş ve sektörler arasında $\% 95$ düzeyinde istatistiksel olarak anlamlı farklılık bulunmuştur. 
Tablo-3 : Çevresel Faaliyetlerin Gerçekleşme Durumunun Sektörler Bazında Mood Medyan Testi Sonuçları

\begin{tabular}{|c|c|c|c|c|}
\hline $\begin{array}{l}\text { Çevresel } \\
\text { Faaliyet }\end{array}$ & $\begin{array}{c}\text { Khi-Kare } \\
\text { Değeri }\end{array}$ & $\begin{array}{c}\text { Genel } \\
\text { Medyan }\end{array}$ & $\begin{array}{c}\text { Serbestlik } \\
\text { Derecesi }\end{array}$ & P Değeri \\
\hline 1 & 15.79 & 1.50 & 8 & $0.046^{*}$ \\
\hline 2 & 16.37 & 2.00 & 9 & 0.06 \\
\hline 3 & 12.36 & 1.00 & 9 & 0.194 \\
\hline 4 & 23.23 & 1.00 & 9 & $0.006 * *$ \\
\hline 5 & 14.17 & 1.00 & 9 & 0.117 \\
\hline 6 & 8.80 & 1.00 & 9 & 0.456 \\
\hline 7 & 11.77 & 1.00 & 9 & 0.226 \\
\hline 8 & 15.57 & 1.00 & 9 & 0.076 \\
\hline 9 & 15.22 & 1.00 & 9 & 0.085 \\
\hline 10 & 7.14 & 1.00 & 9 & 0.622 \\
\hline 11 & 19.90 & 2.00 & 9 & $0.019 *$ \\
\hline 12 & 16.20 & 1.00 & 9 & 0.063 \\
\hline 13 & 6.38 & 1.00 & 9 & 0.701 \\
\hline 14 & 23.36 & 2.00 & 9 & $0.005 * *$ \\
\hline 15 & 15.82 & 1.50 & 9 & 0.071 \\
\hline 16 & 12.66 & 2.00 & 9 & 0.179 \\
\hline 17 & 11.93 & 1.00 & 9 & 0.217 \\
\hline 18 & 13.61 & 1.00 & 9 & 0.137 \\
\hline 19 & 20.32 & 2.00 & 9 & $0.016^{*}$ \\
\hline 20 & 10.97 & 1.00 & 8 & 0.203 \\
\hline 21 & 10.38 & 1.00 & 8 & 0.240 \\
\hline 22 & 19.90 & 2.00 & 9 & $0.019 *$ \\
\hline 23 & 11.60 & 1.00 & 9 & 0.237 \\
\hline 24 & 10.63 & 1.00 & 9 & 0.302 \\
\hline 25 & 14.48 & 1.00 & 9 & 0.106 \\
\hline 26 & 14.50 & 1.00 & 9 & 0.106 \\
\hline 27 & 18.89 & 2.00 & 9 & $0.026^{*}$ \\
\hline 28 & 18.63 & 1.00 & 8 & $0.017^{*}$ \\
\hline 29 & 21.91 & 1.00 & 8 & $0.005 * *$ \\
\hline 30 & 19.76 & 2.00 & 8 & $0.011^{*}$ \\
\hline 31 & 14.45 & 1.00 & 8 & 0.071 \\
\hline 32 & 15.60 & 2.00 & 8 & $0.048^{*}$ \\
\hline 33 & 13.33 & 2.00 & 8 & 0.101 \\
\hline 34 & 10.38 & 1.00 & 8 & 0.240 \\
\hline 35 & 8.07 & 1.00 & 8 & 0.426 \\
\hline
\end{tabular}

$* \mathrm{p}<0.05 * *$ p $<0.01$ 
Çevresel faaliyetlerin işletmelerde gerçekleşme durumunun işletmelerin hukuki statüsü (anonim ve limited şirket olmaları) açısından da farklılık gösterip göstermediği araştırılmıştır. Mood Medyan testi ile her bir çevresel faaliyetin gerçekleşme durumu için hukuki statü medyanları karşılaştırılmış ve sonuçlar Tablo-4' de verilmiştir. Söz konusu tabloda yer alan test sonuçları incelendiğinde;

- 5. Yatırım politikalarının çevresel etkileri dikkate alınmaktadır,

- 6. Çevresel performansın iyileştirilebileceği alanlar belirlenmektedir,

- 12. Yatırımların çevre dostu faaliyetlere yönelmesi sağlanmaktadır

- 21. İşletmede atık yönetimi birimi vardır,

- 26. Çevresel emisyonun ölçümü ve zarar verici boyuta gelmesinin önlenmesi sağlanmıştır

faaliyetlerine verilen yanıtların hukuki statü medyanlarının karşılaştırılmasına ilişkin istatistiklerin olasılık düzeyleri, $\mathrm{p}<0.01$ olarak elde edilmiştir. $\mathrm{Bu}$ sonuca göre anonim ve limited şirketler arasında \%99 düzeyinde istatistiksel olarak anlamlı farklılık bulunmuştur. Ayrica;

- 8. İşletmede mevcut ve ortaya çıkacak çevre sorunlarıyla ilgilenilmekte ve bunların çözümü için stratejiler belirlenmektedir,

- 9. Potansiyel acil durumlar için çevresel tehlike ve risk değerlendirmesi yap1lmaktadır,

- 13. İşletmenin önemli çevresel etkileri belirlenmiştir,

- 18. Çevresel maliyetler tanımlanmıştır

- 25. Geri dönüşümlü malzeme kullanılmaktadır,

- 35. İşletmede çevresel performansın denetlenmesi söz konusudur

faaliyetlerine verilen yanıtlar için ise anonim ve limited şirketler arasında \% 95 düzeyinde istatistiksel olarak anlamlı farklılık bulunmuştur. 
Tablo-4 : Çevresel Faaliyetlerin Gerçekleşme Durumunun İşletmelerin Hukuki Statüsü Bazında Mood Medyan Testi Sonuçları

\begin{tabular}{|c|c|c|c|c|}
\hline $\begin{array}{l}\text { Çevresel } \\
\text { Faaliyet }\end{array}$ & $\begin{array}{c}\text { Khi-Kare } \\
\text { Değeri }\end{array}$ & $\begin{array}{c}\text { Genel } \\
\text { Medyan }\end{array}$ & $\begin{array}{c}\text { Serbestlik } \\
\text { Derecesi }\end{array}$ & $P$ Değer \\
\hline 1 & 0.8 & 1 & 1 & 0.370 \\
\hline 2 & 0.00 & 2 & 1 & 0.998 \\
\hline 3 & 0.86 & 1 & 1 & 0.355 \\
\hline 4 & 3.82 & 1 & 1 & 0.051 \\
\hline 5 & 8.28 & 1 & 1 & $0.004 * *$ \\
\hline 6 & 9.81 & 1 & 1 & $0.002 * *$ \\
\hline 7 & 0.84 & 1 & 1 & 0.359 \\
\hline 8 & 5.97 & 1 & 1 & $0.015^{*}$ \\
\hline 9 & 4.90 & 1 & 1 & $0.027^{*}$ \\
\hline 10 & 3.63 & 1 & 1 & 0.057 \\
\hline 11 & 2.31 & 2 & 1 & 0.128 \\
\hline 12 & 7.91 & 1 & 1 & $0.005^{* *}$ \\
\hline 13 & 6.31 & 1 & 1 & $0.012 *$ \\
\hline 14 & 0.50 & 2 & 1 & 0.482 \\
\hline 15 & 5.83 & 1 & 1 & 0.016 \\
\hline 16 & 1.30 & 2 & 1 & 0.255 \\
\hline 17 & 2.75 & 1 & 1 & 0.098 \\
\hline 18 & 5.47 & 1 & 1 & $0.019 *$ \\
\hline 19 & 0.93 & 2 & 1 & 0.335 \\
\hline 20 & 0.55 & 1 & 1 & 0.458 \\
\hline 21 & 9.49 & 1 & 1 & $0.002 * *$ \\
\hline 22 & 0.30 & 2 & 1 & 0.586 \\
\hline 23 & 0.00 & 1 & 1 & 0.974 \\
\hline 24 & 0.77 & 1 & 1 & 0.380 \\
\hline 25 & 3.97 & 1 & 1 & $0.046^{*}$ \\
\hline 26 & 11.76 & 1 & 1 & $0.001 * *$ \\
\hline 27 & 2.61 & 2 & 1 & 0.106 \\
\hline 28 & 0.34 & 1 & 1 & 0.557 \\
\hline 29 & 3.63 & 1 & 1 & 0.057 \\
\hline 30 & 2.18 & 2 & 1 & 0.140 \\
\hline 31 & 1.58 & 1 & 1 & 0.209 \\
\hline 32 & 3.38 & 2 & 1 & 0.066 \\
\hline 33 & 0.9 & 2 & 1 & 0.343 \\
\hline 34 & 1.16 & 1 & 1 & 0.281 \\
\hline 35 & 4.93 & 1 & 1 & $0.026^{*}$ \\
\hline
\end{tabular}




\section{SONUÇ VE ÖNERILLER}

İzmir ilinde farklı sektörlerde faaliyet gösteren işletmelerde çevre muhasebesi uygulamasına ve diğer çevresel alanlara yönelik faaliyetlerin gerçekleşme durumuna genel olarak \% 57.37 ile "evet”, \% 17.98 ile "düşünülmekte" yanıtının verilmiş olması, işletmelerde çevre bilincinin oluşmaya başladığını göstermektedir. Çalışmada $\% 60$ ve üstü evet yanıtı verilerek gerçekleştiği belirtilen ilk altı faaliyet arasında; işletmelerde atık ve enerji yönetiminin söz konusu olduğu, çevresel emisyonun ölçümü ve zarar verici boyuta gelmesinin önlendiği, mevcut ve ortaya çıkacak çevre sorunlarının ele alındığı ve bunlar için stratejiler belirlendiği, doğal kaynakların korunması için enerji ve malzeme kullanımı verimliliği çalışmaları yapıldığı ve atıkların kullanılabilir ekonomik değerleri olan ürünlere dönüştürülmesinin söz konusu olduğu görülmüştür.

Çevre muhasebesi uygulamasına yönelik faaliyetlerin gerçekleşme durumuna verilen evet yanıt oranları ise; işletmenin önemli çevresel etkileri belirlenmiştir faaliyeti için \% 70.91 iken, çevresel maliyetler tanımlanmıştır \% 57,14, her bir çevresel etkinin maliyetinin nereye kaydedileceği belirlenmiştir \% 51.85, işletmede gözden kaçırılmış çevresel gelirler veya maliyet düşürücü imkânlar saptanmıştır \% 50, çevre muhasebesi uygulamasında kimlerin görev alacağı belirlenmiştir \% 36.84 ve çevre muhasebesi uygulamasında mevcut muhasebe sistemi gözden geçirilmiştir için ise \% 35.85 çıkmıştır.

Çalışma bulgularının değerlendirilmesi sonucunda çevresel faaliyet-yanıt etkileşiminin istatistiksel olarak anlamlı çıkması dikkat çekicidir. İşletmelerin sağlık konusunun ön plana çıktığı, çevresel performans ve halk sağlığına yönelik iyileştirmelerin yapılması, Ar-Ge çalışmaları ile çevre dostu mamuller geliştirilmesi ve çevre muhasebesi uygulamasında mevcut muhasebe sisteminin gözden geçirilmesi faaliyetlerine verdiği düşünülmekte yanıtları beklenen frekansın iki kat üzerinde gerçekleşmiştir. Buna karşılık çevre raporu konusunun ön plana çıktığı, çevresel etkinlikler ile ilgili olarak kamuoyuna yönelik çevre raporu 
düzenlenmektedir faaliyetine verilen evet yanıtlarındaki beklenen frekansa göre azalma dikkat çekmektedir. Bu tür saptamalar Khi-Kare katkı bileşenlerinin açıklayıcı veri analizi kapsamında incelenmesi sonucunda ortaya çıkmıştır. Benzer şekilde işletmelerin komşularına yönelik (gürültü, koku vd. şikayetlerin belirlenmesi için) çevre anketi yapılması ve çevre sloganı oluşturma faaliyetlerinin evet yanıtları, beklenen frekansların bir hayli altında çıkmıştır.

Çevresel faaliyetlerin işletmelerde gerçekleşme durumunun gerek sektörler gerekse işletmelerin hukuki statüleri itibariyle farklılıklarının araştırılması sonucunda ise, bazı faaliyetler için anlamlı farklılıklar saptanmıştır. Örneğin "işletmenin komşularına yönelik çevre anketi yapılmaktadır" faaliyeti sektörler bazında, "çevresel emisyonun ölçümü ve zarar verici boyuta gelmesinin önlenmesi" faaliyeti ise hukuki statü bazında en belirgin farklılaşmaya sahip olmuştur.

Araştırma kapsamına giren işletmelerin \% 79.63 ‘̈ çevre muhasebesi uygulamasına üst yönetimin destek verdiğini belirtmiştir. Çevre muhasebesinden beklenen yararın sağlanması açısından üst yönetim desteğinin olması ve işletmenin önemli çevresel etkilerinin belirlenmesi faaliyetinin gerçekleştirilmesi olumlu bir gelişmedir. İşletmelerin çevre muhasebesi uygulamasında; öncelikle mevcut muhasebe sistemini gözden geçirmesi ve etkin bir çevre muhasebesi bilgi sistemini oluşturması, sistemde konuyla ilgili uzman kimlerin görev alacağını belirlemesi, çevresel maliyetlerin tanımlanması ve etkin yönetilmesi faaliyetlerine ağırlık vermesi, Muhasebe ve Finansal Raporlama Standartları (TMS/TFRS) kapsamında ve yasalara uygun olarak faaliyetlerini gerçekleştirmesi gerekmektedir. İşletmelerin işletme içi ve dışı ilgi gruplarının çevresel beklentilerini karşılama yönünde, yukarıda çevresel faaliyetyanıt etkileşiminin vurgulandığı faaliyetlerini de kısa sürede gerçekleştirmesi ve çevresel bilgilerini düzenli olarak çevre raporları ile iletmesi önem kazanmaktadır. İşletmelerin, devletin, kredi veren kurum ve kuruluşların, üniversitelerin ve kamunun karşılıklı dayanışma 
içinde olması, toplumda çevre bilincinin oluşmasına ve çevresel faaliyetlerin artmasına katkı sağlayacaktır.

\section{KAYNAKLAR}

Akatay, A. ve Aslan, Ş. (2008) "Yeşil Yönetim ve İşletmeleri ISO 14001 Sertifikası Almaya Yönelten Faktörler", Dokuz Eylül Üniversitesi Sosyal Bilimler Enstitüsü Dergisi, 10(1): 313339.

Alagöz, A. ve İrdiren, D. (2013) "Maliyet Muhasebesi Bakış Açısı İle İşletmelerde Çevre Maliyetleri ve Yönetimi”, Sosyal ve Ekonomik Araştırmalar Dergisi, 13 (26): 424-449.

Ali, M.M., Rashid, M.M. ve Islam, M.A. (2010) "Environmental Accounting and Its Applicability in Bangladesh", ASA University Review, 4(1):23-37. January-June, 23-37.

Alpaslan, H.İ., Çatıkkaş, Ö. ve Öktem, B. (2012) "Türkiye Finansal Raporlama Standartları Kapsamında Çevresel Maliyetlerin Değerlendirilmesi ve Uygulama Örneği”, 1. Uluslararası Muhasebe ve Finans Sempozyumu (ISAF), 31 Mayıs-2 Haziran, Gaziantep.

Aslanertik, B.E. ve Özgen, I. (2007) "Otel İşletmelerinde Çevresel Muhasebe”, İşletme Fakültesi Dergisi, 8 (2): 163-179.

Beredugo, S.B. (2014) "Environmental Accounting and Social Responsibility Disclosure on the Earning Capacity of Nigerian Manufacturing Firms", Journal of Economics and Sustainable Development, 5(14): 66-73.

Cavlı, M. (2009) "Şirket Çevreciliği Ekseninde Türkiye'deki Şirketlerin Çevresel Sorumlulukları”, Yüksek Lisans Tezi, Ankara Üniversitesi, Sosyal Bilimler Enstitüsü, Ankara.

Çelik, M. (2007) "Çevreye Duyarlı Muhasebe”, MUFAD Muhasebe ve Finansman Dergisi, 33: 151-161.

De Beer, P. ve Friend, F. (2006) "Environmental Accounting: A Management Tool For Enhancing Corporate Environmental And Economic Performance", Ecological Economics, 58 (3): $548-560$.

Deniz, T. ve Türker, A. (2012) “Çevresel Muhasebe ve Uygulamaları”, Journal of the Faculty of Forestry, Istanbul University, 62 (1): 115-132.

Eltaib, E.E. (2012) "Environmental Accounting Disclosure of Australian Oil and Gas Companies", Master Thesis, School of Accounting and Finance, University of Wollongong, Australia.

EPA Project (1995) An Introduction To Environmental Accounting As A Business Management Tool: Key Concepts and Terms, EPA 742-R-95-001, June, Washington, D.C., ABD. 
Gale, R.J.P. ve Stokoe, P.K.(2001) "Environmental Cost Accounting and Business Strategy", Christian N. Madu (Ed.) Handbook of Environmentally Conscious Manufacturing,: 119-135. Kluwer Academic Publishers.

Gönel, F.D. ve Atabarut, T. (2005) Şirketlerin Yeni Yönetim Aract: Çevresel Muhasebe, TÜSİAD Yayın No: 2005-06/404, İstanbul: Lebib Yalkın Yayımları.

Güvemli, O. ve Gökdeniz, Ü. (1996) “Çevre Muhasebesindeki Gelişmeler”, MÖDAV Dergisi, Muhasebe Öğretim Üyeleri Bilim ve Dayanışma Vakfı, 4: 23-24.

Kırlıoğlu, H. ve Can, A.V. (2006) "Çevresel Muhasebede Kavramsal Tartışmaların Gelişimi ve Analizi”, MUFAD Muhasebe ve Finansman Dergisi, 32: 61- 71.

Kolar, J. ve O'connor, M. (2004) 'Natural Resources and Environmental Accounting in The Czech Republic: An Overview of Methodology and Results", International Journal of Environment and Pollution, 15 (6): 589-616.

Korukoğlu, A. (2011) “İşletmelerde Çevre Muhasebesi: İzmir İli Uygulaması”, Ege Akademik Bakış, 11 (1): 81-89.

Korukoğlu, A. (2014) "İ̧̧letmelerin Çevre Muhasebesi Konularına Yaklaşımlarının Analizi”, Ege Akademik Bakış, 14 (3): 481-491.

Larojan, C. ve Thevaruban, J.S. (2014) "Impact of Environmental Management Accounting Practices on Financial Performance of Listed Manufacturing Companies in Sri Lank", 3rd International Conference on Management and Economics (ICME), 26-27 February, Sri Lanka

Lazol, İ., Muğal, E. ve Yücel, Y. (2008). "Sürdürülebilir Bir Çevre İçin Çevre Muhasebesi ve KOBİ'lere Yönelik Bir Araştırma”, MUFAD Muhasebe ve Finansman Dergisi, 38: 56-69.

Li, A. (2014) "Research on the Environmental Accounting Information Disclosure of China's Petroleum Industry”, 3rd International Conference on Science and Social Research (ICSSR) June 14-15, China,

Maria, J. Masanet-Llodra (2006) "Environmental Management Accounting: A Case Study Research on Innovative Strategy", Journal of Business Ethics, 68 (4): 393-408.

Özbirecikli, M. (2002) Çevre Muhasebesi. Ankara: Naturel Kitap ve Yayıncılık.

Reynolds, G.N. ve Tilt, C.A.(2013) An Investigation of How Management Accounting Supports Corporate Environmental Strategy: Case Studies of Australian Businesses, http://www.apira2013.org/proceedings.

Savage, D.E., Ligon, P.J. ve Lomsek, J. (2001) Environmental Management Accounting: Policies and Linkages, United Nations, New York.

Schaltegger, S. ve Burritt, R. (2000) Contemporary Environmental Accounting: Issues, Concepts and Practice, Published by Greenleaf Publishing Limited Aizlewood's Mill. 
Yakhou, M. ve Dorweiler, V.P. (2004) "Environmental Accounting: An Essential Component of Business Strategy", Business Strategy and the Environment, 13: 65-77.

Yüksel, H. (2003) "İşletmelerin Çevreye Duyarlı Üretim Faaliyetlerinin Ampirik Bir Çalışma İle Değerlendirilmesi”, Endüstri Mühendisliği Dergisi, 14 (2): 21-32.

Zhang, J., Guo, H. ve Wang, W. (2009) "The Influence of Financial Situation on Environmental Information Disclosure in China's Chemical Industry", International Journal of Global Environmental Issues, 9 (3): 272-286. 